\title{
In silico Analysis of Copper Nanoparticles Synthesizing Bacteria Contributing Towards Big Data Bank
}

\author{
Priyanka Kashyap*, Poonam Shirkot, Praveen Khatri, \\ Pooja Thakur and Vikrant Gautam
}

Department of Biotechnology, Dr. YS Parmar University of Horticulture and Forestry, Nauni, Solan (HP) 173 230, India

*Corresponding author

\section{A B S T R A C T}

\section{Keywords}

rRNA, Diversity,

Homology,

Identification and

Copper

nanoparticles

Article Info

Accepted:

26 December 2018

Available Online:

10 January 2019
16S rRNA gene sequences are most commonly used for determination or studying the bacterial phylogeny and taxonomy because its present in almost all bacterial population. 16S rRNA gene sequence is remaining conversed during evolution so that 16S rRNA gene identification method is widely used for identification of bacterial diversity. In this study, bacterial population was isolated from soil sample for copper nanoparticles synthesis and maximum copper synthesizing bacteria further used for characterization. Bacteria firstly characterized by using microscopic and biochemical characters and then confirmed by using 16S rRNA gene technology. In this experiment, we have used blastn, Cluster W, MEGA6.0 software to find homology and phylogenetic analysis to identification of bacterial isolate. We have identified Stenotrophomonas maltophilia strain SCS1.1 with a noble trait such as to synthesizing copper nanoparticles.

\section{Introduction}

Isolation of bacteria from different kinds of environments such as soil, water, hot water springs, saline conditions, humid areas, dry and temperate regions is very important to study the new properties of microbial population. Populations in microbial communities or ecosystem may interact and cooperate to obtain nutrients from environment and allows waste products from one group of microbes to serve as nutrients for another. Microorganisms are known to be capable of synthesizing inorganic molecules that are deposited either intracellularly or extracellularly (Plaza et al., 2014). Calamity of environment led to the survival of only those organisms which have meticulously adapted to the survival strategies designed by nature. The efficient natural nanomachineries in form of enzymes, organic molecules and the intracellular or extracellular shuttlers have been endowed with special characteristics for survival. Toxic metals spilled off by human civilization are contaminating the elixir of life i.e. water. Soil also cannot escape this 
cataclysmic contamination (Wang et al., 2011). Eradication of the toxicity of metals is the only other alternative for biological system to survive. Hence, living organisms with their proficient nanomachineries transform toxic metal ions into non toxic ones ( $\mathrm{Lu}$ et al., 2006). Copper nanoparticles synthesizing bacteria have been isolated from different sources such that as specific mines, municipal waste, marine samples etc.

In the last decade, sequencing of $16 \mathrm{~S}$ rRNA gene and comparison between 16S rRNA gene used and phylogeny has confirmed (Spiegelman et al., 2005). Advances in computational biology and bioinformatics has been remarkable in the last few decades, that established large scale sequencing, structure and function determination, gene prediction and specific landmarks on the genome as well as proteome analysis on strong foundations.

NCBI and EMBL are various online service used when homologous sequences are to be compared which are essential for further analyses. Use of these tools in multiple sequence computational phylogenetic analysis, multiple sequence alignment and proteomics has been carried out. Keeping in view above considerations, the present study was designed for isolation, biochemical characterization and molecular identification of copper nanoparticles synthesizing bacteria by use of $16 \mathrm{~S}$ rRNA technology to determine evolutionary rates of different bacterial isolate and close match between them by using various bioinformatics.

\section{Materials and Methods}

\section{Sample collection for isolation bacteria}

A survey was conducted for selection of various sites of Solan District of Himachal Pradesh for the collection of samples. Only one site was selected for isolation of bacterial population for synthesis of copper nanoparticles. Different samples such as soil, pebbles and rock matting were collected from selected site in sterilized containers.

\section{Isolation and screening of copper nanoparticles synthesizing bacteria}

Nutrient agar enriched with $2 \mathrm{mM} \mathrm{CuSO} 4$ solution using standard pour plate method (David et al., 2014) by incubation at $37^{\circ} \mathrm{C}$ for 24 hrs. Copper nanoparticles synthesizing bacterial isolates were characterized morphologically and biochemically and confirmed using PCR-16S rDNA technology.

\section{DNA isolation and PCR amplification of rRNA gene}

Genomic DNA of selected bacterial isolate was extracted using Genomic DNA extraction Mini kit (Real Genomics) used as template for amplification of the $16 \mathrm{~S}$ rrna gene using universal primers for $16 \mathrm{~S}$ rrna gene of bacteria. Amplifications were performed using thermal cycler and with a temperature profile standardized for $16 \mathrm{~S}$ rrna gene amplification. PCR amplification was carried out in $0.2 \mathrm{ml}$ PCR tubes with $20 \mu$ l reaction volume containing 5U/reaction of Taq DNA polymerase, 10X PCR buffer with $1.5 \mathrm{mM}$ $\mathrm{MgCl} 2,10 \mathrm{nmol} /$ reaction primers, $0.5 \mathrm{mM}$ deoxynucleotide triphosphate (dNTPs) and template DNA. Initial cycle of $3 \mathrm{~min}$ at $95^{\circ} \mathrm{C}$ followed by 35 cycles of $30 \mathrm{sec}$ at $95^{\circ} \mathrm{C}$, annealing temperature of $50^{\circ} \mathrm{C}$ for $30 \mathrm{sec}$, elongation step of $2 \mathrm{~min}$ at $72^{\circ} \mathrm{C}$ and a final extension step of $10 \mathrm{~min}$ at $72^{\circ} \mathrm{C}$.

\section{Gel electrophoresis}

One percent agarose was used for analysis of PCR products (GeNei, Bangalore, India) dissolved in $1 \mathrm{X}$ TAE buffer containing (10 $\mathrm{mg} / \mathrm{ml}$ ) ethidium bromide and images were taken through Gel Documentation Unit 
(Syngene, UK). Size of the amplified products was determined by 100bp standard molecular weight ladder or markers (GeNei, Bangalore, India). The selected bacterial isolate were further characterized using $16 \mathrm{~S}$ rrna gene technology and genomic DNA extracted from these isolates were selectively amplified using PCR technology with Universal primers B27F and U1492R for $16 \mathrm{~S}$ rrna gene were used.

\section{$16 \mathrm{~S}$ rrna gene Sequencing}

The 16S rRNA purified PCR products (100ng concentration) were subjected to sequencing using the chain termination method developed by Sanger and his coworkers in 1977 (Applied Biosystem Inc). Sequencing of 16S rrna gene fragments of selected bacterial isolates was done from both forward and reverse directions. The selected sequences obtained were subjected to BLASTn search to find homology. The percentages of sequence matching were also analyzed and the sequences were submitted to NCBI-Gen Bank and accession numbers were obtained for the same.

\section{Results and Discussion}

Bacterial identification is more accurate identified using molecular method as compared to the traditional techniques including morphological and biochemical characters. In recent times comparison of the bacterial 16S rrna gene sequence which are conserved in nature has emerged as a preferred genetic technique. Total 49 bacterial isolates were obtained only single isolate SCS1.1 synthesis maximum copper nanoparticles (Fig. 1). Morphologically and biochemically SCS1.1 identified as gramnegative bacteria. Total genomic DNA of selected bacterial isolates was extracted successfully then amplified using PCR technology and were characterized using $16 \mathrm{~S}$ rrna gene technology. After 35 cycles of PCR amplification, universal primers for $16 \mathrm{~S}$ rrna gene were able to successfully amplify $16 \mathrm{~S}$ rrna gene and produced an amplicon of expected size i.e. $1500 \mathrm{On}$ the basis of results obtained from 16S rrna gene analysis. On the basis of results obtained from 16S rrna gene analysis and in addition to $\mathrm{G}+\mathrm{C}$ content analysis (Table 1), the selected bacterial isolate were found to belong to genera Stenotrophomonas. Further in silico analysis pertaining to the sequence, so obtained, was carried out using various bioinformatics tools available online. Analysis of $16 \mathrm{~S}$ rrna gene of the selected bacterial isolates revealed homology with various other $16 \mathrm{~S}$ rrna gene sequences. BLASTn search of selected bacterial sequences with the most similar $16 \mathrm{~S}$ rrna gene sequences of the GenBank database (http://www.ncbi.nlm.nih.gov/blast) revealed the closest sequence identities from the sequence database (Marchler- Bauer et al., 2000; Pruitt et al., 2005).

Table.1 Nucleotide base composition in the query sequence (SCS1.1 isolate)

\begin{tabular}{|l|l|c|}
\hline \multirow{2}{*}{ Nitrogenous Base } & Nucleotide Count \\
\hline Adenine (A) & Total & Percentage (\%) \\
\hline Thymine (T) & 270 & $\mathbf{2 0}$ \\
\hline Cytosine (C) & 321 & $\mathbf{2 7}$ \\
\hline Guanine (G) & 402 & $\mathbf{3 0}$ \\
\hline G+C & 310 & $\mathbf{2 3}$ \\
\hline A+T & 711 & $\mathbf{5 4 . 6 2}$ \\
\hline
\end{tabular}


Table.2 Percent homology of nucleotide query sequence of SCS1.1 with other nucleotide sequences present in the database using BLASTn analysis

\begin{tabular}{|c|c|c|c|c|}
\hline $\begin{array}{l}\text { Accession } \\
\text { Number }\end{array}$ & Closest match & $\begin{array}{l}\text { Length } \\
\text { (bp) }\end{array}$ & $\begin{array}{l}\text { Query } \\
\text { cover }\end{array}$ & $\begin{array}{ll}\text { Per cent } \\
\text { Similarity }\end{array}$ \\
\hline LN558615.1 & $\begin{array}{l}\text { Stenotrophomonas maltophilia isolate } \\
\text { AAIII-2 }\end{array}$ & 1430 & $99 \%$ & $97 \%$ \\
\hline MH703447.1 & Stenotrophomonas sp. strain Gamma-16 & 1481 & $95 \%$ & $98 \%$ \\
\hline MF942711.1 & Uncultured bacterium clone 1_deep & 1512 & $95 \%$ & $98 \%$ \\
\hline CP022053.2 & $\begin{array}{l}\text { Stenotrophomonas maltophilia } \text { strain } \\
\text { FDAARGOS_325 chromosome, complete } \\
\text { genome }\end{array}$ & 4851512 & $95 \%$ & $98 \%$ \\
\hline MF354012.1 & $\begin{array}{l}\text { Stenotrophomonas maltophilia strain } \\
\text { KUGK130 16S }\end{array}$ & 1475 & $95 \%$ & $98 \%$ \\
\hline KY908461.1 & Stenotrophomonas sp. strain M5 & 1320 & $95 \%$ & $98 \%$ \\
\hline KY407758.1 & $\begin{array}{l}\text { Uncultured Stenotrophomonas sp. clone KR } \\
245\end{array}$ & 1445 & $95 \%$ & $98 \%$ \\
\hline KT034431.1 & Stenotrophomonas sp. & 1480 & $95 \%$ & $98 \%$ \\
\hline KT580582.1 & $\begin{array}{l}\text { Stenotrophomonas maltophilia strain CanL- } \\
56\end{array}$ & 1506 & $95 \%$ & $98 \%$ \\
\hline$\underline{\text { KP790032.1 }}$ & $\begin{array}{l}\text { Stenotrophomonas maltophilia strain } \\
\text { SBB17 }\end{array}$ & 1492 & $95 \%$ & $98 \%$ \\
\hline KF059260.1 & Stenotrophomonas sp. Db-1 & 1537 & $95 \%$ & $98 \%$ \\
\hline$\underline{\mathrm{KC894543.1}}$ & Uncultured bacterium clone H96 & 1525 & $95 \%$ & $98 \%$ \\
\hline$\underline{\mathrm{KC871534.1}}$ & Pseudomonas sp. An 18 & 1505 & $95 \%$ & $98 \%$ \\
\hline$\underline{\mathrm{JQ291604.1}}$ & Pseudomonas hibiscicola strain HPG72 & 1507 & $95 \%$ & $98 \%$ \\
\hline JN644502.1 & $\begin{array}{l}\text { Stenotrophomonas maltophilia strain } \\
\text { ROI_3A }\end{array}$ & 1476 & $95 \%$ & $98 \%$ \\
\hline FR853777.1 & Uncultured bacterium- clone 1661 & 1512 & $95 \%$ & $98 \%$ \\
\hline FR853763.1 & Uncultured bacterium -clone 1643 & 1510 & $95 \%$ & $98 \%$ \\
\hline$\underline{\mathrm{HQ407233.1}}$ & Stenotrophomonas maltophilia strain E56 & 1511 & $95 \%$ & $98 \%$ \\
\hline GU564359.1 & Stenotrophomonas sp. Bt-45 & 1453 & $95 \%$ & $98 \%$ \\
\hline GU391033.1 & $\begin{array}{l}\text { Stenotrophomonas maltophilia strain } \\
\text { CCF0025 }\end{array}$ & 1497 & $95 \%$ & $98 \%$ \\
\hline$\underline{\text { FJ193149.1 }}$ & $\begin{array}{l}\text { Uncultured Stenotrophomonas sp. clone } \\
\text { GI6-10b-C05 }\end{array}$ & 1503 & $95 \%$ & $98 \%$ \\
\hline
\end{tabular}


Fig.1 Screening of copper nanoparticles synthesizing bacterial isolates from Solan District

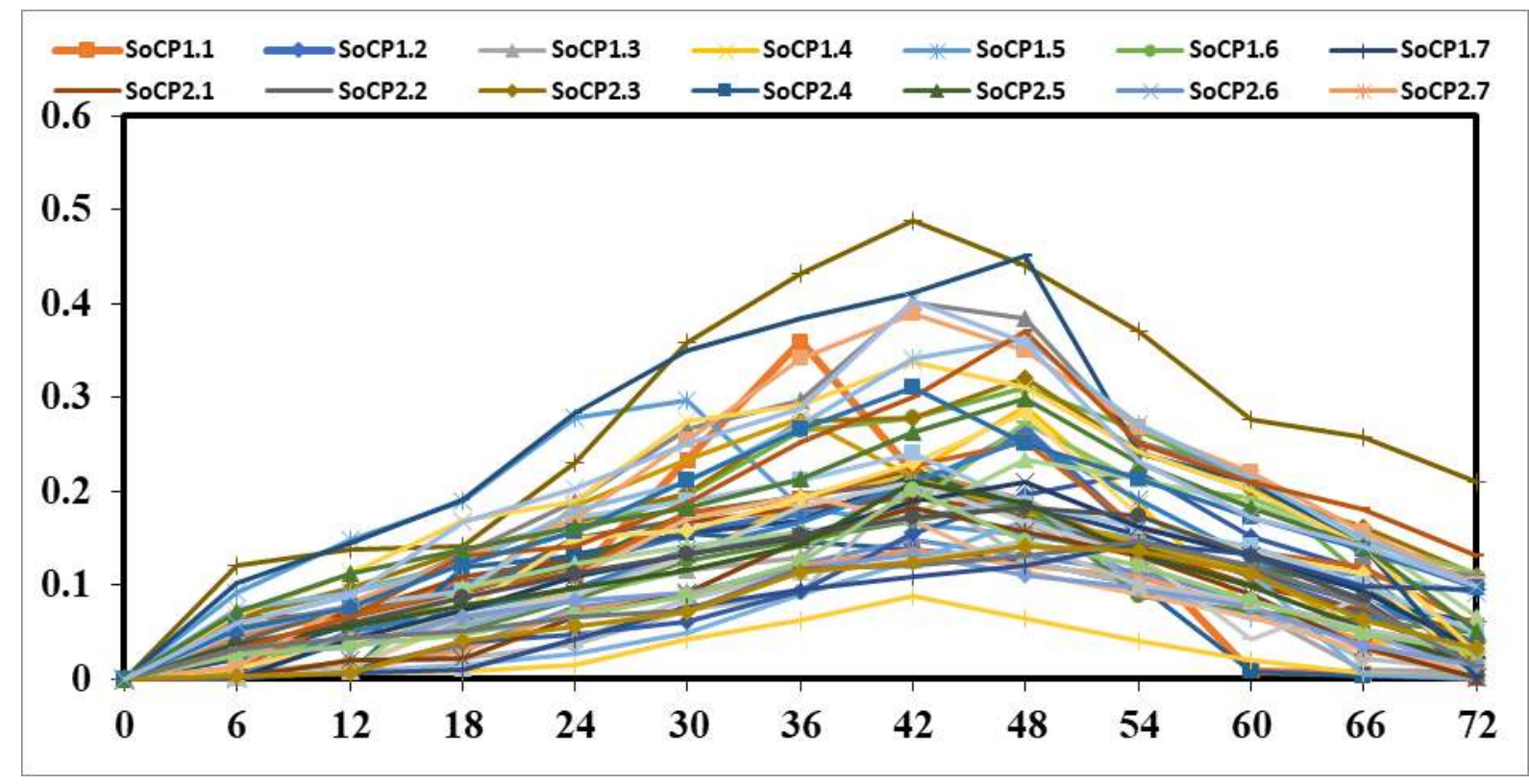

The percentages of sequence matching were also analyzed. The $16 \mathrm{~S}$ rrna gene sequence analysis showed $97 \%$ similarity with Stenotrophomonas maltophilia isolate AAIII2 (Table 2) and the sequence was submitted to NCBI-Gen Bank and accession numbers was MK183005. Similarly, 16S rRNA gene technology along with in silico analysis have been successfully used to identify metal nanoparticles synthesizing bacterial isolates, Bacillus cereus strain CS11 (Das et al., 2014), Stenotrophomonas maltophilia strain OS4 (Oves et al., 2013), Bacillus pumilis (Modi et al., 2015) and Bacillus subtilis (Bhuvaneswari et al., 2016). copper nanoparticles synthesizing bacteria has been isolated and identified by Kaur et al., (2015) and Tiwari et al., (2016) as Kocuria flava and Bacillus cereus respectively using $16 \mathrm{~S}$ rRNA technology.

In conclusion, it has been found that isolate SCS1.1 which was isolated from Solan Chambaghat Soil, have maximum ability to synthesized copper nanoparticles. SCS1.1 isolate found to be gram negative by morphological and biochemical characteristics. In this study , universal primers B 27F 5 -AGAGTTTGATCCTGGC TCAG-3 and U1492R 5'-GGTTACCTTG TTACGACTT- 3 with an annealing temperature of $50^{\circ} \mathrm{C}$ produced an amplified product near $1500 \mathrm{bp}$ of $16 \mathrm{~S}$ rrna gene of selected bacterial isolate. Molecularly SCS1.1 isolate partially identified as Stenotrophomonas maltophilia which show 97\% similarity with Stenotrophomonas maltophilia isolate AAIII-2. In this study, this bacteria was reported first time in India for synthesis of copper nanoparticles.

\section{References}

Plaza GA, Chojniak J and Banat IM. 2014. Biosurfactant mediated biosynthesis of selected metallic nanoparticles. International Journal of Molecular Sciences 15: 13720-13737.

Wang P, Liu Y, Yin Y, Jin H, Wang S, Xu F, Zhao S and Geng X. 2011. Paper Diversity of Microorganisms Isolated from the Soil Sample surround Chroogomphus rutilus in the Beijing Region. International Journal of 
Biological Sciences, 7(2): 209-220.

Lu WT Tian B, Li T and Yu J. 2006. Nanoparticles and their biological and environmental applications. Journal of Bioscience and Bioengineering 102(1): $1-7$.

Spiegelman D, Whissell G, and Greer CW. 2005. A survey of the methods for the characterization of microbial consortia and communities. Canadian Journal of Microbiology 51: 355-386.

Marchler-Bauer A, Panchenko A R, Shoemaker B, Thiessen PA, Geer LY and Bryant SH. 2000. CDD: a database of conserved domain alignments with links to domain three dimensional structure. Journal of Nucleic Acids Research 30: 281-283.

PruittK D, Tatusova T and Maglott DR. 2005. NCBI reference sequence: a cultured non-redundant sequence database of genomes, transcripts, and proteins. Nucleic Acids Research. 33: 501-504.

Das VL, Thomas R, Varghese TR, Soniya EV, Mathew J and Radhakrishnan EK. 2014. Extracellular synthesis of silver nanoparticles by the Bacillus strain CS 11 isolated from industrialized area.
Biotechnology 4: 121-126.

Oves M, Khan MS, Zaidi A, Ahmed AS, Ahmed F, Ahmad E, Sherwani A, Owais M and Azam A. 2013. Antibacterial and cytotoxic efficacy of extracellular silver nanoparticles biofabricated from chromium reducing novel OS4 strain of Stenotrophomonas maltophilia. PLOS One 8: 140-159.

Modi S, Pathak B and Fulekar MH. 2015. Microbial synthesized silver nanoparticles for decolorization and biodegradation of azo dye compound. Journal of Environment and Nanotechnology 4(2): 37-46.

Kaur H, Dolma K, Kaur N, Malhotra A, Kumar N, Dixit P, Sharma D, Mayilraj $S$ and Choudhury AR. 2015. Marine microbe as nano-factories for copper biomineralization. Biotechnology and Bioprocess Engineering 20: 51-57.

Tiwari M, Jain P, Hariharapura RC, Narayanan K, Bhat U, Udupa $\mathrm{N}$ and Rao JV. 2016. Biosynthesis of copper nanoparticles using copper- resistance Bacillus cereus, a soil isolate. Process Biochemistry 10767: 01-09.

\section{How to cite this article:}

Priyanka Kashyap, Poonam Shirkot, Praveen Khatri, Pooja Thakur and Vikrant Gautam. 2019. In silico Analysis of Copper Nanoparticles Synthesizing Bacteria Contributing Towards Big Data Bank. Int.J.Curr.Microbiol.App.Sci. 8(01): 3078-3083. doi: https://doi.org/10.20546/ijcmas.2019.801.328 